This item was submitted to Loughborough's Research Repository by the author.

Items in Figshare are protected by copyright, with all rights reserved, unless otherwise indicated.

\title{
Technological spillovers and productivity in Italian manufacturing firms
}

PLEASE CITE THE PUBLISHED VERSION

LICENCE

CC BY-NC-ND 4.0

\section{REPOSITORY RECORD}

Piga, Claudio, and Giuseppe Medda. 2019. "Technological Spillovers and Productivity in Italian Manufacturing Firms". figshare. https://hdl.handle.net/2134/2968. 
ISSN 1750-4171

\title{
DEPARTMENT OF ECONOMICS
}

\section{DISCUSSION PAPER SERIES}

\section{Technological Spillovers and Productivity in Italian Manufacturing Firms}

\author{
Giuseppe Medda ${ }^{\dagger}$
}

Claudio A. Piga

\section{WP 2007 - 17}

Dept Economics

Loughborough University

Loughborough

LE11 3TU United Kingdom

Loughborough

Tel: + 44 (0) 1509222701

Fax: + 44 (0) 1509223910

http://www.lboro.ac.uk/departments/ec 


\title{
Technological Spillovers and Productivity in Italian Manufacturing Firms
}

\author{
Giuseppe Medda ${ }^{\dagger}$ \\ DEIR \\ University of Sassari, Italy
}

\author{
Claudio A. Piga* \\ Economics Department, \\ Loughborough University, UK; and \\ Rimini Centre for Economic \\ Analysis (RCEA), Rimini, Italy
}

July 2007

\begin{abstract}
We study whether a firm's total factor productivity dynamics is positively influenced by its own R\&D activity and by the technological spillovers generated at the intra- and intersectorial level. Our approach corrects simultaneously for the endogeneity and the selectivity biases introduced by the use of a firm's own R\&D as a regressor. The evidence suggests that a firm's involvement in R\&D activities accounts for significant productivity gains. Firms also benefit from spillovers originating from their own industries, as well as from innovative upstream sectors.
\end{abstract}

JEL classification: C21, C80, D24, O30

Keywords: R\&D; TFP; selectivity; treatment effect.

"Contact Author. Email: c.a.g.piga@lboro.ac.uk; Loughborough, Leicestershire, LE11 3TU, UK, Tel: +44 (0) 1509 222759; Fax: (+44)-(0) 1509223910.

†email: gmedda@yahoo.it; DEIR, Via Torre Tonda 34,07100 Sassari. 


\section{Introduction}

Since the pioneering work of Griliches (1979), productivity studies have looked at the technological spillovers as an important side product of R\&D activities. Newly produced technology can be only partially patented or kept secret: the (at least partial) non-excludability of knowledge, along with the property of non-rivalry, imply that the use of a new product or process by the innovating firm does not prevent other firms from using the same product or process. Consequently, a firm's production function depends on its specific inputs, as well as on the level of knowledge available in the economy. Thus, a positive difference characterizes the social and the private returns to a firm's R\&D activity.

In this paper, we estimate the private returns to $R \& D$ using a cross section of Italian manufacturing firms, while simultaneously controlling for possible industrial technological spillovers. The latter are broken down into intra-industry spillovers, measured by the total value of the $R \& D$ investment in the sector a firm belongs to, and inter-industry spillovers. These are further divided depending on the intensity of the links a sector has with the other innovative sectors. Such links are captured by the extent to which a sector trades (purchases and sells) with other sectors.

Thus, we consider two kinds of external spillover flows: those coming from upstream industries (supply-driven spillovers) and those from the customers of the firm (demand-driven spillovers). Employing input-output tables at the 2-digit industry level, each firm is viewed as a customer and a supplier. The distinction is relevant because Bartelsman et al. (1994) and Morrison and Siegel (1999) find that the externalities from suppliers can differ significantly from the customer-induced spillovers, both in terms of magnitude and in the way they can interact with a firm's own technological capability.

To estimate the returns to private $R \& D$ we argue that firms rationally determine whether to invest in $\mathrm{R} \& \mathrm{D}$, so that the sub-sample of firms performing $\mathrm{R} \& \mathrm{D}$ is not random and thereby introduces a selection bias in the productivity equation. Furthermore, the econometric approach also addresses the issue that the level of $R \& D$ investments may be related to the expected gain in productivity. Both issues of endogeneity and selectivity are dealt with by employing the traditional approach suggested in Heckman (1979) as well as the more recent control functions methods illustrated in Wooldridge (2002). These are particularly useful to take account of the endogeneity of the intensity of R\&D expenditures.

After controlling for all these econometric aspects, our findings support the hypothesis of a positive relationship between a firm's innovative activity and its productivity gains. Indeed, $R \& D$ 
active firms exhibit a productivity growth, which is 3-5\% higher than non-R\&D firms. Moreover, increasing $R \& D$ expenditure over sales by one percent appears to lead to an increase in total factor productivity growth of more than one percent in most specifications.

To provide the backdrop against which our study is built, the next two Sections survey, respectively, the literature on technological spillovers and the previous empirical papers that adopted variations to the analytical framework known as the R\&D capital stock model (Lichtenberg and Siegel, 1991). In Section 4 we describe our empirical strategy to deal simultaneously with the selectivity and the endogenous variable biases, while Section 5 illustrates the data sources and describes the variables used in the estimations. Results are reported in Section 6, which is followed by the concluding remarks.

\section{Industrial technological spillover}

The theoretical and empirical literature identifies two major concepts of technological spillovers (Griliches, 1991): rent-spillovers and knowledge-spillovers. Rent-spillovers occur when new goods are purchased at prices below those that would fully reflect the value of technological improvements from R\&D investments. They can be considered as a pecuniary externality from upstream industries, whose competitive market structure may not allow firms to fully transform higher quality into higher prices.

Knowledge-spillovers derive from technology's incomplete excludability. Innovation by one firm is adopted by "adjacent" firms, thus enhancing their productive and innovative capabilities. Knowledge spillovers arise exclusively as an intangible transmission of ideas; in principle, they are not embodied in traded goods, and thus they do not necessarily require economic transactions. In practice, such mechanisms as the transactions of intermediate or capital goods and the mobility of high-skilled workers are generally responsible for inter-firm knowledge transfers (Romer, 1990).

Proximity to the source of externalities is crucial to a better assimilation of other firms' technology. Several studies have investigated the relation between the location of a firm, defined either in a geographical or economic space, and its innovative and productive performance. The spatial spillover literature tries to estimate the effects of innovative activities performed by geographically close firms, universities or other research centers. ${ }^{1}$ The industry spillover literature

${ }^{1}$ Audretsch and Feldman (1996), and Peri (2005) are empirical studies on this issue. See Piga and PoyagoTheotoky (2005) for a theoretical analysis. 
examines how a firm's technology level and productivity performance may depend on R\&D efforts by the firms belonging to the same sector as well as to other related sectors.

One strand of literature assumes that technological spillovers exist only between firms operating within well-defined borders outside of which no knowledge flows. In some study investigating intra-region spillovers, the borders are determined geographically (Adams and Jaffe, 1996; Orlando, 2004). Other studies define economic spaces within manufacturing sectors to explore intra-industry spillovers (Bernstein and Nadiri, 1989; Los and Verspagen, 2000).

A more general approach allows technology spillovers to flow across regions or industries. It assumes that the benefit a firm can derive from others firms' technological efforts is inversely related to their distance from the firm emanating the externality (Wolff and Nadiri, 1993; Keller, 2002). More precisely, it is assumed that the intensity of firm $i$ 's flow of incoming spillover is

$$
S_{i}=\sum_{j \neq i}^{n} w_{i j} R_{j},
$$

where subscript $j$ indicates the origin of spillover (e.g., a firm, an industry or a region); $R$ is a measure of technological capital, usually proxied by R\&D expediture; $w_{i j}$ is an inter-industry weight representing the inverse of the distance between firm $i$ and the source of externalities $j$.

To construct industry weights, previous studies have used trade flows statistics at the sectorial level. This method relies on the assumption that the more industry $i$ buys from and sells to industry $j$, the more it can benefit from technological spillovers originating from industry $j .^{2}$ Bartelsman et al. (1994) employ a method that distinguishes between the potential spillover from downstream linkages (demand-driven spillovers) and upstream linkages (supply-driven spillovers). They find that spillovers originated from R\&D conducted by suppliers affect long run growth more than spillovers from customers' R\&D, while demand-driven externalities cause only short-run fluctuations. Paul and Siegel (1999) find analogous results, with a stronger magnitude for supplydriven spillovers even in the short-run.

However, technological knowledge, which is available in an economy as a quasi-public good, is not always appropriable without cost. In order to take advantage of others' technological improvements, firms need the ability "to recognize the value of new, external knowledge, assimilate it, and apply it to commercial ends" (Cohen and Levinthal, 1990, p. 128). This ability, called

${ }^{2}$ See Terleckyj (1974) and Wolff and Nadiri (1993) among others, where weights are proportional to the interindustry trade flows and are derived from input-output matrix coefficients. 
absorptive capacity, is primarily built on own $\mathrm{R} \& \mathrm{D}$ investment aimed to foster an internal critical mass of knowledge, which permits a firm to recognize and integrate external technologies.

\section{Analytical framework and micro-level literature}

We adopt the conventional R\&D capital stock model in Lichtenberg and Siegel (1991), extended to include the external spillovers effects into each firm's production function. Assume a Cobb-Douglas production function with constant return to scale with respect to conventional inputs (labor, capital, materials, and energy), with extra factors of production represented by the stock of internal R\&D capital (Mansfield, 1980; Griliches, 1995), and the external R\&D capital (Los and Verspagen, 2000):

$$
Y_{i}=A\left(\prod X_{m}^{\alpha_{m}}\right) \cdot R_{i}^{\beta} S_{i}^{\gamma}
$$

where: $Y_{i}$ is firm $i$ 's output (net sales); $A$ is disembodied, Hicks-neutral, technology stock evolving at the exogenous rate $\lambda ; X_{m}$ represents a vector of $m$ conventional factors of production; $\alpha_{m}$ are their output elasticities; $R_{i}$ is firm $i$ 's internal R\&D capital stock, with output elasticity $\beta$; $S_{i}$ represents the technology spillover available to firm $i$, with elasticity $\gamma$.

We assume a zero depreciation rate for R\&D (Griliches and Lichtenberg, 1984), so that the accumulation dynamics equals R\&D current expenditures:

$$
\dot{R}_{i}=\frac{d R_{i}}{d t}=R \& D_{i}
$$

Denoting the number of firms with which firm $i$ interacts as $n$, the spillover effect is a weighted sum of other firms' R\&D capital stocks, where the weights measure the intensity of the interaction between firm $i$ and firm $j$. If weights are constant over time, then from (1):

$$
\dot{S}_{i}=\sum_{j \neq i}^{n} w_{i j} \dot{R}_{j}=\sum_{j \neq i}^{n} w_{i j} R \& D_{j}
$$

Taking the conventional definition of total factor productivity $T F P=\frac{Y}{\prod X_{m}^{\alpha_{m}}}$, assuming perfectly competitive factors markets, taking logs and differentiating with respect to time, we obtain a relationship linking TFP growth, internal R\&D intensity, and R\&D spillovers from other firms:

$$
\left(\frac{T \dot{F P}}{T F P}\right)_{i}=\lambda+\rho \frac{R \& D_{i}}{Y_{i}}+\mu \sum_{j \neq i}^{n} w_{i j} \frac{R \& D_{j}}{Y_{j}}
$$


where $\rho$ is the marginal product, or rate of return, of internal research capital, and $\mu$ is the rate of return from technological spillovers. In the remainder of this Section, we provide a survey of the existing measures of $\rho$ and $\mu$.

Table 1 presents some descriptive statistics for the estimates of the internal rate of return to R\&D available from the existing literature. They are derived from 102 estimates of $\rho$, included in 18 articles, which were selected according to the following criteria: the datasets include at least 30 observations at the plant- or firm-level; a measure of R\&D intensity is used (mostly R\&D over sales, value added or number of employees); either TFP or labor productivity growth or both are the dependent variables. In general, estimates are higher when TFP growth is the dependent variable: $23.8 \%$ is the average rate of return, $39.4 \%$ when considering $5 \%$ significant estimates only. The estimates are highly dispersed, ranging from the value of $-122 \%$ found by Clark and Griliches (1982) in their pool of American manufacturing business units over the period 1970-80, to the $231 \%$ return to basic research by the manufacturing firms in Link (1981b). Although returns vary greatly according to econometric specification, country, database dimension, period and type of $R \& D$, most studies indicate that $R \& D$ investments seem to have a positive role in enhancing productivity at the micro level.

Table 1 about here

Micro-level studies of technological spillovers present an even greater heterogeneity with respect to measure of spillovers and empirical specification. Table 2 lists 22 articles distinguished according to the measure of distance used to weigh technological intensities, the dependent variable, and the major findings.

With regards to the dependent variable, some studies focus on the impact of spillovers over production costs (Bernstein, 1988; Bernstein and Nadiri, 1989), or on such measures of firms' performance as profit margins and other financial indicators (Geroski et al., 1993; Jaffe, 1986). Van Reenen (1997) studies the impact of spillover effects over employment inside the firm, while all the other studies use productivity or total production measures.

As far as distance measures are concerned, some authors do not weigh technology indicators, that is, they use the same weight for firms inside the same space (industry or region). These studies analyze intra-industry or intra-region spillovers (Antonelli, 1994; Bernstein, 1988; Los and Verspagen, 2000, among others). Some studies of inter-industry spillovers measure distance among firms by means of inter-sectorial flows of intermediate goods; others employ patents of innovations classification to construct technology spaces. In Adams and Jaffe (1996) and 
Orlando (2004), a measure of geographical distance between firms is employed, while Macdissi and Negassi (2002) model the external technological spillover on the basis of firms' resources devoted to cooperation and capital flows.

Most studies present positive and significant estimates of elasticities and return to spillovers. Jaffe $(1988,1989)$ finds positive effects from technologically near firms, in a sample of American firms in the Seventies. Capron and Cincera (1998) find similar results for a sample spanning the period 1987-97. In a sample of Canadian firms between 1978 and 1988, Bernstein (1988) distinguishes between private and social returns to R\&D and between intra and inter industry spillovers. He finds higher estimates of social returns relative to private returns. Los (2000) and Los and Verspagen (2000) find higher returns to inter industry spillovers in comparison to intra-industry ones; intra-nation spillovers are found to be stronger than international spillovers (Adams and Jaffe, 1996; Branstetter, 2001).

Table 2 about here

\section{$4 \quad$ Empirical strategy}

To study how firms' productivity growth is related to own R\&D and external technological spillovers, we pursue the following estimation strategy on. Building on (5), we estimate two germane types of models:

$$
\begin{aligned}
& \left(\frac{T \dot{F P}}{T F P}\right)_{i}=\beta_{1}^{\prime} X_{i}+\beta_{1}^{R \& D} D_{-} R E_{i}+\beta_{1}^{S P I L L} \sum_{k}\left(w_{i k} \frac{R E}{Y}\right)_{k}+u_{i} \\
& \left(\frac{T \dot{F P}}{T F P}\right)_{i}=\beta_{2}^{\prime} X_{i}+\beta_{2}^{R \& D}\left(\frac{R E}{Y}\right)_{i}+\beta_{2}^{S P I L L} \sum_{k}\left(w_{i k} \frac{R E}{Y}\right)_{k}+e_{i}
\end{aligned}
$$

where $D_{-} R E_{i}$ is a dummy indicating whether firm $i$ is engaged in $\mathrm{R} \& \mathrm{D},(R E / Y)_{i}$ is the ratio of firm $i$ 's own R\&D spending $\left(R E_{i}\right)$ over total sales $\left(Y_{i}\right),(R E / Y)_{k}$ represents the total $\mathrm{R} \& \mathrm{D}$ spending over total sales in each manufacturing sector $k$ and $w_{i k}$ is a measure of distance between firm $i$ and sector $k$, which is discussed below. $X_{i}$ is a vector of exogenous variables such as regional dummies, plus a constant. TFP growth is the dependent variable, and $u_{i}$ and $e_{i}$ are classical disturbance terms.

A potential selection problem in estimating eq. (6a) may arise because the sample of firms involved in $R \& D$ is not random. That is, it is possible that productivity growth and the decision to 
carry out R\&D are jointly determined (Wooldridge, 2002). ${ }^{3}$ For simplicity, suppose that each firm's decision on whether to engage itself in $R \& D$ can be modeled according to the following probit or logit specification:

$$
D_{-} R E_{i}=\gamma^{\prime} W_{i}+\varepsilon_{i}
$$

where $D_{-} R E_{i}=1$ if $R E_{i}>0$ and $D_{-} R E_{i}=0$ if $R E_{i}=0, W_{i}=Z_{i}+X_{i}, Z_{i}$ is a vector of variables which explain, along with $X_{i}$, a firm's decision to engage in R\&D. The residuals in (6a) and (7) are correlated as follows:

$$
\left(\begin{array}{l}
u_{i} \\
\varepsilon_{i}
\end{array}\right) \approx N\left[\left(\begin{array}{l}
0 \\
0
\end{array}\right),\left(\begin{array}{cc}
\sigma_{u}{ }^{2} & \sigma_{u \varepsilon} \\
& 1
\end{array}\right)\right] .
$$

If $\sigma_{u \varepsilon} \neq 0$, then $D_{-} R E_{i}$ is endogenous in (6a), and OLS would produce biased estimates. We try to correct the bias due to a dummy endogenous variable by following two strategies. First, we employ the standard two-step procedure illustrated in Heckman (1979), where the inverse Mill's ratio (IMR) from (7) is used as an additional regressor in (6a). A t-test for the significance of the IMR's coefficient can be considered as a test on the presence of selection. ${ }^{4}$ Second, following the procedure 18.1 outlined in Wooldridge (2002, pp.621-625), the fitted values from (7) are employed as an instrument for $D_{-} R E_{i}$, and (6a) is then estimated using Instrumental Variables (IV) techniques.

To estimate (6b), a further refinement of the above procedures is necessary, because the selection mechanism involves both the decision of whether to invest in R\&D as well as how much to invest. To account for both forms of endogeneity, following problem 18.8 in Wooldridge (2002, pp.643-644), we first calculate the predicted values from the following Tobit model:

$$
\left(\frac{R E}{Y}\right)_{i}=\gamma^{\prime} W_{i}+v_{i} .
$$

These are used as instruments for $(R E / Y)_{i}$ in the IV estimation of (6b).

\footnotetext{
${ }^{3}$ Unlike firm $i$ 's own R\&D, sector $k$ 's R\&D intensity is assumed to be exogenous. That is, following Romer
} (1986), we rule out the possibility that a single firm can influence the average R\&D intensity of the sector to which it belongs.

\footnotetext{
${ }^{4}$ See Medda et al (2006) for another application and Vella and Verbeek (1999) for a theoretical analysis.
} 


\section{Data}

\section{A - Data Sources}

Our empirical analysis relies on two main data sources: sectorial-level data, provided by the Italian National Institute of Statistics (Istat) and firm-level data, collected by a bank formerly known as Mediocredito Centrale and now part of Capitalia Bank. The latter consist of a survey from a stratified sample of nearly 5,000 firms. The procedures for data collection were mixed: a sampling procedure was adopted for firms hiring less than 500 employees. The stratification was in accordance with size, industry and location. The sample dimension for each stratum was determined according to Neyman's formula, so as to allow rescaling to the universe at the level of each administrative geographical region. For firms with more than 500 employees, the survey covered the entire universe. Overall, the survey, which has been repeated over the years, generated a sample which is considered to be representative of the Italian manufacturing industry (Medda et al., 2006; Parisi et al., 2006; Piga and Atzeni, 2007; Piga and Vivarelli, 2004).

The survey design considered three types of data: 1) balance sheet data for the 1989-2000 period; 2) data related to measurable company characteristics for the 1998-2000 period (i.e. employment, investment and R\&D outlays etc.); 3) questionnaire data regarding firm's relationship with customers and suppliers, composition of sales, competitive environment, group membership and position within the group, industry characteristics, ownership concentration, and other qualitative information. Such data was used to construct all the firm-level variables.

\section{B - Dependent Variables}

The dependent variable, TFP growth, was computed using the "long difference" method:

$$
\left(\frac{T \dot{F P}}{T F P}\right)=\frac{\Delta Y}{Y}-\sum_{j} \alpha_{j}\left(\frac{\Delta X_{j}}{X_{j}}\right) .
$$

It is obtained as a residual from the difference between sales growth over the period 19982000 and the weighted sum of the conventional inputs growth, i.e. capital, materials, energy, services, and labor. More precisely, the capital stock growth is computed as the growth rate of tangible assets net of depreciation, while labor input is calculated as the number of non-R\&D employees to limit the double counting problem as R\&D is included as a regressor (Griliches and Mairesse, 1984). The $\alpha_{j}$ weights represent each factor's elasticity of production. It should be noted that under the assumption of perfectly competitive markets for factor inputs, these elasticities are equal to the respective cost shares. To work these out, the shares of labor costs and materials and 
energy costs over total costs were calculated for the initial and the final year, and then their average value was taken. Following Lichtenberg and Siegel (1991), the cost share of capital was calculated as a residual, i.e., as the complement to one after the cost shares of labor and material and energy were deducted. ${ }^{5}$

\section{C-Own R\&D and Spillovers}

The $D \_R E$ dummy assumes the unit value if a firm's R\&D expenditure in 1998 is strictly positive. This is used as a regressor in (6a) and as the dependent variable in (7). The ratio of R\&D expenditures over sales represents $(R E / Y)_{i}$ in $(6 \mathrm{~b})$ and (9). To reduce potential simultaneity problems, we used R\&D expenditures only from the first year of the period under analysis, i.e. 1998.

Based on the previous discussion, different types of technological spillovers are constructed using the sectorial-level data from the ISTAT. First, the variable Intra-industry spillover measures the 1997 R\&D spending over total sales for each of the 21 manufacturing sectors in our sample (Istat, 2004). It constitutes a rough measure of knowledge spillovers, and its inclusion assumes that technology is a public good inside a manufacturing sector (Romer, 1986).

Second, following the previous general discussion in Section 2 and Bartelsman et al (1994) in particular, we assume that each firm belonging to manufacturing sector $j$ can potentially benefit from externalities coming from industry $k$, and that the magnitude of the externality depends on the intensity of trade flows between sector $j$ and sector $k$. To obtain a measure of trade intensity between sectors we use data from the input-output matrix for the Italian manufacturing sectors in the year 1998 (Istat, 2004b). Thus, we computed two external spillovers indicators.

The first, denoted as Supply-driven spillovers from other industries, captures the intensity of the potential $\mathrm{R} \& \mathrm{D}$ spillovers that a firm in industry $j$ receives from the $\mathrm{R} \& \mathrm{D}$ performed in all the other $k$ industries that supply industry $j$. It corresponds to the weighted sum of the R\&D expenditure in each industry $k$, where the weights are given by the share of purchases of industry $j$ from industry $k$, for $j \neq k$.

${ }^{5}$ All variables expressing monetary values were deflated to the 1998 base-year, using value added deflators for 21 two-digit industries: these were also disaggregated by geographical location to take into account differences between the input prices in the North-West, the North-East, the Center, and the South of Italy. All deflators come from Istat regional accounts. 
Similarly, the second indicator, Demand-driven spillovers from other industries, measures the same weighted sum, but the weights are specified as the share of sales of industry $j$ to industry $k$, for $j \neq k$. In the Appendix, two Tables report the above weights.

Both the R\&D variables and the related spillovers are expected to have a positive impact on the dynamics of Total Factor Productivity.

\section{D-Exogenous Variables}

To estimate (7) and (9), the set of exogenous variables were chosen according to previous similar works carried out on earlier releases of the Mediocredito Centrale survey (Piga and Vivarelli, 2004; Medda et al., 2005 and 2006). We provide here a brief description

The (log of) number of employees is included to control for firm size and its effect on the propensity to undertake R\&D (Cohen et al., 1987). The share of intangible assets accounts for the propensity to create reputation (Teece, 1992) and absorptive capacity (Cohen and Levinthal, 1990). We control for the effects that a firm's debt liabilities have on its propensity to invest in R\&D by including the ratio of long and short term debt, assuming that innovative firms were facilitated by access to the credit market (Piga and Vivarelli, 2004). A dummy equal to one if the firm is the holding or controls other firms in a pyramidal group aims at capturing the effects that being part of a group of companies engenders on the likelihood to engage in innovative activities (Bianco and Nicodano, 2006). An exporting firm is identified by a dummy on the grounds that competing in international markets stimulates the search for new products/processes, while a firm's age is expected to capture the accumulative process of knowledge and thus the innovative capacity of the firm. The human capital variable is an index measuring the average years of education retained by employee over the number of years needed to obtain a degree (de la Fuente and Domenech, 2000) and constitutes a proxy for the absorptive capacity of the firm.

After variables computation and accounting for missing values, we obtained a data set of 3,120 firms. As far as the outlier observations are concerned, following Hoaglin et al. (1983) a lower and an upper threshold for the TFP growth and the employment growth were identified according to the following rules:

$$
\begin{aligned}
& \text { lower bound }=\text { first quartile }-3 \times \text { interquartile range; } \\
& \text { upper bound }=\text { third quartile }+3 \times \text { interquartile range. }
\end{aligned}
$$

The outliers' elimination reduced the sample size to 3077 firms. 
Table 3 shows a description of the data set employed for our empirical analysis. Only $28.2 \%$ of firms in the data set have presented positive $R \& D$ expenditures, that is, have performed $R \& D$ activities. The share of firms with positive R\&D varies between $60 \%$ in professional instruments industry (although only 10 firms belonging to this sector are included in our data set), and 12.7\% in printing and publishing sector, to $2.7 \%$ in professional instruments and $1 . \% 8$ in optical industries.

Average TFP growth in 1998 - 2000 was negative (-1.8\%) in almost all industries, with few exceptions in industrial machinery and vehicle and other transportation industries.

Table 3 about here

\section{$6 \quad$ Results}

Table 4 presents results from the probit and tobit estimates of the selection equations (7) and (9), where the dependent variables are, respectively, 1) a firm's likelihood to invest in R\&D, and 2) how much to invest in R\&D.

Table 4 about here

Although it is not the main purpose of this paper to explain the mechanism driving a firm's decision to engage in $R \& D$ activities and their associated intensity (for a survey see Cohen and Levin, 1989 and Crepon et al., 1998), we now briefly comment on the findings in Table 4. Firm's size (proxied by the number of employees) is strongly and positively related to propensity to carry on $\mathrm{R} \& \mathrm{D}$, while age of firm and position in a group don't seem to influence significatively the choice. The negative and highly significant coefficients on the constant terms indicate that small firms located in the South of Italy are less likely to report positive R\&D expenditure. As in Medda et al. (2006), we find that that export intensity is positively associated with the probability of engaging in R\&D. Our results also suggest that formal innovative activity is more likely to occur in firms that have a greater proportion of long term debts over total assets and high human capital index.

The models in Table 4 are used to obtain the inverse Mill's ratio and the fitted values needed as instruments in the productivity equations (6a) and (6b), whose estimates, obtained using the 
procedures discussed above, are reported in Table $5 .{ }^{6}$ More precisely, when the dummy for R\&D is one of the regressors, we employ either the Heckman's two step method or Wooldridge's Instrumental Variable approach. The last set of estimates includes the level of R\&D spending, instrumented by the predicted values from (9).

Table 5 about here

Estimates shown in the first two columns are very similar: both Heckman's and Wooldridge's procedure provide positive and significant estimates of the effect of conducting R\&D, with coefficients equal, respectively, to 0.032 and 0.033 . By including the intra-industry spillovers variable, the effect of own $R \& D$ rises to 0.051 in both models. Also, intra-industry spillovers have positive and significant effects, that is, firms benefit from average R\&D intensity performed in the sector where they belong. In the Heckman's procedure, a negative and significant IMR implies the presence of a negative selection mechanism into R\&D activities. Running simple OLS for eq. (6) would yield underestimation of the effect of performing R\&D on TFP growth and underestimation of the private return to $R \& D$.

The last columns of Table 5 reports the estimates for the private return to R\&D expenditures as well as of the intra-industry spillovers effect. The findings are qualitatively similar to the ones where the innovative activity is proxied by a dummy. A major difference regards the magnitude of the returns to a firm's own R\&D expenditure: a 10\% increase of which enhances TFP by about $12 \%$ and $16.5 \%$, depending on the specifications. The larger return of R\&D expenditures, compared to that of the R\&D dummy, is seen as a regularity typically observed when passing from a dichotomous to a continuous selection mechanism (Wooldridge, 2002). Intra-industry spillovers are not significant, although positive. This result can be explained by the inclusion of the variable of own R\&D intensity in place of the dummy for R\&D activity. Indeed, the coefficient for the $R \& D$ intensity variable captures both the private returns to $\mathrm{R} \& \mathrm{D}$ performed by the firm and the absorptive capacity effect related to external sources of knowledge. The simultaneous inclusion of both private $R \& D$ intensity and total industry $R \& D$ increases the return to private $R \& D$ and dampens the effect of the spillover generated within each industry.

\footnotetext{
${ }^{6}$ Wooldridge (2002) argue that, for the purpose of estimating treatment effects, selection models need not to be correctly specified (p. 623). What matters is finding estimates of IMR and fitted values orthogonal to independent variables in the productivity equation.
} 
As discussed above, firms can benefit from the technological progress originating in different industries, where trade serves as a means for the inter-industry transmission of knowledge. In Bartelsman et al. (1994), Morrison Paul (2002) and Morrison Paul and Siegel (1999), spillovers can differ significantly depending on the kind of linkages between firms and industries. In particular, these studies find significant differences between spillover effects originating from customer and those related to the supplier of a firm or industry (see also Mun and Nadiri, 2002).

We distinguish between externalities originating along the supply chain and estimate separately demand-driven spillovers (Table 6) and supply-driven spillover (Table 7). For both Tables we employ the previously defined two-stage IV methods to deal with the endogeneity of a firm's own R\&D activity and intensity.

Previously reported findings regarding the endogenous variables are confirmed in Table 6, both in terms of significance and magnitude, although the coefficients for R\&D spending are now slightly larger (1.84 and 1.85). Intra-industry spillovers, which provide an alternative to sectorial dummies, continue to be significant but inter-industry spillovers from customer sectors do not appear to be associated with productivity enhancements. The possibility of cumulative effects linking an industry's own R\&D intensity with external spillovers is not supported by the data, as the coefficient for the interaction of the two variables suggests.

The negative effect, although not significant, of externalities from other customer industries suggests that the firms in our sample do not receive any positive externality from the interaction with their customers. Similar findings are reported in Bartelsman et al (1994) and Mun and Nadiri (2002) who find little or no cross-sectional relation between customer driven spillovers and productivity. In our sample, this may be because our firms largely supply sectors with low R\&D investments, or because they sell very little to R\&D intensive sectors, or finally because they produce for the final market. Our evidence is thus consistent with the well-known specialization of Italian firms in traditional and scale intensive sectors (Antonelli, 1994).

Table 6 about here

The coefficients of the Supplier-driven spillovers are reported in Table 7. They are significantly positive, and larger than those obtained for the demand-driven spillovers, in line with results found by Bartelsman et al. (1994) and Morrison and Siegel (1999). Intra-industry spillovers are non-significant, while own $R \& D$ continues to play a crucial role in all estimates and methods.

Thus, purchases from R\&D intensive sectors enhance our firm's productivity, especially when they are already engaged in innovative activities. It would seem therefore that part of the 
improvements in productivity in our sample could be ascribed to technological progress embodied in the acquired physical capital. To test whether such an effect tends to be reinforced in R\&D intensive sectors that enjoy large supply driven spillovers, the variables identifying the intra- and the inter-industry spillovers are interacted. However, there appear to be no systematic effect of this kind. Indeed, the interaction between the external spillovers and an industry's total investment in R\&D does not seem to be conducive to significant productivity improvements, suggesting that their effects are independent and non-cumulative.

Table 7 about here

Finally, to check the robustness of the previous findings, we estimated a model similar to those in Tables 6 and 7, where the Supply and the Demand inter-industry spillover variables were replaced by their mean value. We do not report such estimates, as they are qualitatively similar to those in Table 7.

\section{Conclusions}

In this paper we have pursued three main objectives. First, we surveyed the existing literature linking productivity dynamics to $R \& D$ investment and its spillovers. Second, we applied a number of treatment effect methods to account for the endogeneity and the selectivity biases arising in the estimation of a productivity regression when the R\&D activity at the firm level is used as an explanatory variable. Third, following an established approach, we have investigated the role of technological inter- and intra-sectorial spillovers in driving productivity changes in a sample of manufacturing Italian firms.

The evidence further consolidates the view of a firm's involvement in R\&D activities as an important driver of productivity gains. Although studies based on previous releases of the Mediocredito-Capitalia dataset also report similar results (Medda et al., 2005 and 2006; Parisi et al. 2006), the present study innovates by finding that technological spillovers appear to be responsible for a positive growth of total factor productivity. In particular, firms seem to benefit from the knowledge spillovers generated in their own industries, possibly because it addresses technological aspects pertaining to products and production processes that are shared, and found relevant, among all the firms. Similarly, the knowledge embodied in the products purchased from suppliers seems to enhance productivity. However, we find no systematic evidence of a cumulative effect between intra- and inter-sectorial spillovers, suggesting that they both operate independently and in a noncumulative fashion. 


\section{References}

ADAMS J.D. AND JAFFE, A.B. (1996). "Bounding the Effects of R\&D: An Investigation Using Matched Establishment-Firm Data," Rand Journal of Economics, 27, 4 700-721.

Aiello, F. AND PUPO, V. (2002). "Il tasso di rendimento degli investimenti in ricerca e sviluppo delle imprese innovatrici italiane”, Rivista di Politica Economica, XCIV, 5-6, 81-117.

Antonelli, C. (1994). "Technological districts localized spillovers and productivity growth. The Italian evidence on technological externalities in the core regions", International Review of Applied Economics, 8, 1, 18-30.

Audretsch, D. AND FELDMAN, M. (1996) "R\&D spillovers and the geography of innovation and production". American Economic Review, 86, 3, 630-640.

Bartelsman, E.J., R.J. CABallero And Lyons, R.K. (1994). "Customer- and Supplier-Driven Externalities", American Economic Review, 84, 4, 1075-1084.

BASANT, R. AND FIKKerT, B. (1993). "Impact of R\&D, Foreign Technology Purchase and Technology spillovers on Indian Industrial Productivity”, United Nations University/INTECH Working Paper No. 18.

BERNSTEIN, J. I. (1988). "Costs of production, intra- and interindustry R\&D spillovers: Canadian evidence”, Canadian Journal of Economics, 21, 324-347.

BERnSteIn, J.I. AND NADIRI, M. I. (1989). "Research and Development and intraindustry spillovers: an empirical application of dynamic duality", Review of Economic Studies, 56, 249-269.

Bianco, M. And Nicodano, G. (2006). "Pyramidal groups and debt”, European Economic Review, 50, 937961.

BRANSTETTER, L.G. (2001). “Are knowledge spillovers international or intranational in scope?”, Journal of International Economics, 53, 1, 53-79.

CAPRON, H. AND CINCERA, M. (1998), "Assessing the R\&D Determinants and Productivity of Worldwide Manufacturing firms", Annales d'Economie et de Statistiques, 49/50, 566-587.

Clark, K.B. AND GRILICHES, Z. (1982). "Productivity growth and R\&D at the business level: Results from the PIMS data Base", NBER Working Papers No. 916.

CohEn, W.M. And LeVIN, R. (1989). "Empirical Studies of R\&D and Market Structure,” in R. Schmalensee and R. Willig, eds., Handbook of Industrial Organization, Amsterdam: North-Holland, 1059-1107.

Cohen, W.M. AND LeVinthal, D.A. (1990). “Absorptive capacity: A new perspective on learning and innovation", Administrative Science Quarterly, 35, 128-152. 
COHEN, W.M., LEVIN, R.C. AND MOWERY, D.C. (1987). "Firm Size and R\&D Intensity: A Re-Examination”, Journal of Industrial Economics, 5, 4, 543-565.

Crepon B., Duguet, E. AND Mairesse, J. (1998). "Research, Innovation and Productivity: An Econometric Analysis at the Firm Level", Economics of Innovation and New Technologies, 7, 115-158.

Criscuolo, C. AND Haskel, J. (2003). "Innovations and Productivity Growth in the UK”, CeRiBA, Centre for Research Into Business Activity, Office for National Statistics.

DE LA Fuente, A. AND DOMENECH, R. (2000). "Human capital Growth regressions: How much difference does data quality make?", Oecd Economics Department Working Papers No. 262.

GEROSKI, P.A., MACHIN, S. AND VAN REENEN, J. (1993): “Innovation and firm profitability", RAND Journal of Economics, 24, 198-211.

GrILICHES, Z. (1979), "Issues in Assessing the Contribution of Research and Development to Productivity Growth", The Bell Journal of Economics, 10, 1, 92-116.

GrilicheS, Z. (1986). "Productivity, R\&D and Basic Research at the Firm Level in the 1970's", American Economic Review, 76, 1 (March), 141-154.

GRILICHES, Z. (1991). “The search for R\&D spillover”, NBER Working Paper No. 3768.

GRILICHES, Z. (1995). "R\&D and Productivity: Econometric Results and Measurement Issues", in P. Stoneman (ed.), Handbook of the Economics of Innovation and Technological Change, Oxford, UK: Blackwell Publishers Ltd.

Griliches, Z. AND LiChtenBerG F. (1984). "Interindustry Technology Flows and Productivity Growth: A Reexamination", Review of Economics and Statistics, 66, 2, 324-329.

GRILICHES, Z. AND MAIRESSE J. (1983), "Comparing Productivity Growth: An Exploration of French and US Industrial and Firm Data", European Economic Review, 21, 89-119.

Griliches, Z. AND MAIRESSE J. (1984), "Productivity and R\&D at the Firm Level", in Z. Griliches (ed.), R\&D, Patents, and Productivity, University of Chicago Press for NBER, 1984, 339-374.

HALl, B.H. AND MAIRESSE J. (1995). "Exploring the Relationship Between R\&D and Productivity in French Manufacturing Firms", Journal of Econometrics, 65, 1, 263-293.

HARHOFF, D. (1998). "R\&D and productivity in German manufacturing firms", Economics of Innovation and New Technologies, 6, 29-49.

HECKMAN, J. (1979). “Sample selection bias as a specification Error”, Econometrica, 47, 153-161.

Hoaglin, D.C., Mosteller, F. AND TUKey J.W. (EDS.) (1983). Understanding Robust and Exploratory Data Analysis. Wiley, New York.

ISTAT (2004). Statistiche sull'innovazione delle imprese, Roma, Istat. 
ISTAT (2004b). Il nuovo sistema input-output, Roma, Istat.

JAFFE, A.B. (1986). "Technological Opportunity and Spillovers of R\&D”, American Economic Review, 76, 984-1001.

JAFFE, A.B. (1988). "R\&D Intensity and Productivity Growth", Review of Economics and Statistics, 70, 431437.

JAFFE, A.B. (1989). “Characterising the 'Technological Position' of Firms, with Applications to Quantifying Technological Opportunity and Research Spillovers", Research Policy, 18, 87-97.

KELLER, W. (2002). "Trade and the Transmission of Technology," Journal of Economic Growth 7, 5-24.

Klomp, L. AND VAN LeEUwen, G. (2001). "Linking Innovation and Firm Performance: A New Approach”, International Journal of the Economics of Business, 8, 343-364.

KWON, H.U. AND INUI, T. (2003). "R\&D and Productivity Growth in Japanese Manufacturing firms", ESRI Discussion Paper Series No. 44.

LiCHTENBERG, F. AND SiEgel, D (1991). "The impact of R\&D investment on productivity - New evidence using R\&D - LRD Data”, Economic Inquiry, 29, 2, 203-228.

LINDSTRÖM, T. (1999). "External Economies at the Firm Level: Evidence from Swedish Manufacturing", Central Bank of Sweden Working Paper Series No. 89.

LINK, A.N. (1981a). Research and Development Activity in U.S. Manufacturing, Proger Publishers, New York.

LINK, A.N. (1981b). "Basic Research and Productivity Increase in Manufacturing: Additional Evidence", American Economic Review, 71, 5, 1111-1112.

LINK, A.N. (1983). “Inter-firm technology flows and productivity growth", Economics Letters, 11, 179-184.

LOS, B. (2000). "The Empirical Performance of a New Interindustry Technology Spillover Measure", in Saviotti, P.P. and Nooteboom, B. (eds.), Technology and Knowledge; From the Firm to Innovation Systems, Cheltenham, Edward Elgar.

LOS, B. AND VERSPAGEN, B. (2000). "R\&D Spillovers and Productivity: Evidence from U.S. Manufacturing Microdata", Empirical Economics, 25, I, 127-48.

MACDISSI, C. AND NEGASSI, S- (2002). "International R\&D spillovers: an empirical study", Economics of Innovation and New Technologies, 11, 2, 77-91.

MANSFIELD, E. (1980). "Basic Research and Productivity Increase in Manufacturing", American Economic Review, 70, 5, 863-873.

Medda, G., Piga, C. AND Siegel D.S. (2005). "University R\&D and Firm Productivity: Evidence from Italy”, Journal of Technology Transfer, 30, 1/2, 199-205. 
MedDA, G., PigA, C. ANd SiEgel, D.S. (2006). "Assessing the Returns to Collaborative Research: FirmLevel Evidence from Italy", Economics of Innovation and New Technology, 15, 1, 37-50.

MORRISON PAUL, C.J. (2002). "Supply and Demand-Driven Spillover and Productivity Growth", Japan and the World Economy, 14, 285-304.

Morrison Paul, C.J. AND Siegel D.S. (1999). "Scale Economies and Industry Agglomeration Externalities: A Dynamic cost Function Approach", American Economic Review, 89, 1, 272-290.

Mun, S.B. AND NADIRI, M.I. (2002). "Information Technology Externalities: Empirical Evidence from 42 U.S. Industries", NBER Working Paper No. 9272.

ODAGIRI, H. AND IWATA, H. (1986). "The impact of R\&D on productivity increase in Japanese manufacturing companies", Research Policy, 15, 13-19.

ORLANDO, M.J. (2004). "Measuring Spillovers from Industrial R\&D: on the Importance of Geographic and Technological Proximity", Rand Journal of Economics, 35, 4, 777-786.

PARISI, ML., A. SEMBEnelli, AND F. SChiAnTARElli. (2006). "Productivity, Innovation and R\&D: Micro Evidence for Italy", European Economic Review, 50, 2037-2061.

PERI, G. (2005). "Determinants of Knowledge Flows and their Effect on Innovation," Review of Economics and Statistics, 87, 2, 308-322.

PIGA, C.A., AND ATZENI, G.. (2007). "R\&D Investment, Credit Rationing and Sample Selection", Bulletin of Economic Research, 59, 149-178.

Piga, C.A., And Poyago-Theotoky, J. (2005). "Endogenous R\&D Spillovers and Locational Choice", Regional Science and Urban Economics, 35, 127-139.

Piga, C.A., AND Vivarelli, M. (2004). "Internal and External R\&D: A Sample Selection Approach", Oxford Bulletin of Economics and Statistics, 66, 4, 457-482.

RAUT, L.K. (1995). "R\&D spillover and productivity growth: Evidence from Indian private firms", Journal of Development Economics, 48, 1-23.

RoMER, P.M. (1986). "Increasing Returns and Long-Run Growth", Journal of Political Economy, 94, 5, $1002-1037$

ROMER, P.M. (1990). "Endogenous Technological Change”, Journal of Political Economy, 98, 5 part 2, 71 102.

SCHERER, F.M. (1982). "Inter-industry Technology Flows and Productivity Measurement", Review of Economics and Statistics, 64, 627-634.

TEECE, D.J. (1992) “Competition, Cooperation and Innovation: Organisational Arrangements for Regimes of Rapid Technological Progress", Journal of Economic Behaviour and Organization, 18, 1, 1-25. 
TERLECKYJ, N.E. (1974). Effects of R\&D on the Productivity Growth of Industries: An Exploratory Study, Washington, D.C.: National Planning Association.

VAN REENEN, J. (1997). "Employment and technological innovation: Evidence from U.K. manufacturing firms", Journal of Labor Economics, 15, 2, 255-284.

Vella, F. AND VERBEEK, M. (1999). "Estimating and Interpreting Models with Endogenous Treatment Effects", Journal of Business and Economic Statistics, 17, 4, 473-478.

WAKELIN, K. (2001). "Productivity Growth and R\&D Expenditure in UK Manufacturing Firms", Research Policy, 30, 7, 1079-1090.

WIESER, R. (2001). "R\&D and productivity: Evidence for European and U.S. firms in the 1990s", WIFO Working Papers No. 159.

WIESER, R. (2005). "R\&D and productivity: Empirical evidence at the firm level", Journal of Economic Survey, 19, 4, 587-621.

WOLFF, E.N. AND NADIRI, M.I. (1993). "Spillover Effects, Linkage Structure, and Research and Development", Structural Change and Economic Dynamics, 4, 315-331.

Wooldridge, J. (2002). Econometric Analysis of Cross Section and Panel Data, Cambridge, The MIT Press. 
Table 1

INTERNAL OR PRIVATE RATE OF RETURN TO R\&D: LITERATURE REVIEW

\begin{tabular}{|c|c|c|c|c|c|}
\hline \multirow[b]{2}{*}{ dependent variable } & \multicolumn{3}{|c|}{ all observations } & \multirow[b]{2}{*}{$\max }$. & \multirow[b]{2}{*}{ obs } \\
\hline & mean & std. dev. & $\min$. & & \\
\hline tfp growth & 0.238 & 0.562 & -1.220 & 2.310 & 37 \\
\hline labor productivity growth & 0.161 & 0.466 & -1.420 & 2.629 & 65 \\
\hline \multicolumn{6}{|c|}{ only at least $5 \%$ significant } \\
\hline tfp growth & 0.394 & 0.503 & 0.047 & 2.310 & 23 \\
\hline labor productivity growth & 0.245 & 0.116 & 0.104 & 0.607 & 33 \\
\hline
\end{tabular}

Articles used to construct this table are: Aiello and Pupo (2005); Clark and Griliches (1982); Criscuolo and Haskel (2003), Griliches (1986); Griliches and Mairesse (1983, 1984); Hall and Mairesse (1995); Klomp and Van Leeuwen (2001); Kwon and Inui (2003); Lichtenberg and Siegel (1991); Link (1981a, 1981b, 1983); Medda, Piga, and Siegel (2005, 2006); Odagiri and Iwata (1986); Wakelin (2001); Wieser (2001).

Table 2

TECHNOLOGICAL SPILLOVER AT THE MCRO LEVEL: A REVIEW

\begin{tabular}{|c|c|c|c|c|c|c|}
\hline authors & country & $\begin{array}{l}\text { Time } \\
\text { span }\end{array}$ & observations & $\begin{array}{c}\text { Measure of } \\
\text { distance }\end{array}$ & $\begin{array}{c}\text { dependent } \\
\text { variable }\end{array}$ & Main results \\
\hline Adams, Jaffe (1996) & USA & $1974-88$ & 19561 & $\begin{array}{l}\text { Geographical } \\
\text { distance }\end{array}$ & Tfp & $\begin{array}{l}\text { Positive impact }(0.01-1.92) \text {; major } \\
\text { influence from national technology } \\
\text { than from international }\end{array}$ \\
\hline Aiello, Pupo (2005) & Italy & $1989-97$ & $380-2254$ & $\begin{array}{l}\text { No distance (intra } \\
\text { industry) }\end{array}$ & Labor productivity & Positive impact $(0.05-0.107)$ \\
\hline Antonelli (1994) & Italy & $1984-85$ & 92 & $\begin{array}{l}\text { No distance (intra } \\
\text { industry) }\end{array}$ & $\begin{array}{l}\text { Labor productivity } \\
\text { growth }\end{array}$ & Non significant estimates \\
\hline Basant, Fikkert (1993) & India & $\begin{array}{c}1974- \\
1983\end{array}$ & 787 & $\begin{array}{l}\text { Position in a patent } \\
\text { space }\end{array}$ & Labor productivity & $\begin{array}{l}\text { Non significant estimates, neither } \\
\text { national nor international }\end{array}$ \\
\hline Bernstein (1988) & Canada & $1978-88$ & 680 & $\begin{array}{l}\text { No distance (intra } \\
\text { industry) }\end{array}$ & Production costs & Positive impact $(0.17-0.24)$ \\
\hline Bernstein, Nadiri (1989) & USA & $1965-78$ & 48 & $\begin{array}{l}\text { No distance (intra } \\
\text { industry) }\end{array}$ & Production costs & Positive impact $(0.09-0.16)$ \\
\hline Branstetter (2001) & $\begin{array}{l}\text { USA, } \\
\text { Japan }\end{array}$ & $1983-89$ & $209-205$ & $\begin{array}{l}\text { Position in a patent } \\
\text { space }\end{array}$ & $\begin{array}{l}\text { Total product } \\
\text { growth }\end{array}$ & $\begin{array}{l}\text { Positive impact from national } \\
\text { spillovers }(0-0.83) \text {; non significant or } \\
\text { negative impact of international } \\
\text { spillovers }\end{array}$ \\
\hline Capron, Cincera (1998) & $\begin{array}{l}\text { Europe, } \\
\text { USA, } \\
\text { Japan }\end{array}$ & $1987-97$ & $101-378-133$ & $\begin{array}{l}\text { Position in a patent } \\
\text { space }\end{array}$ & $\begin{array}{l}\text { Total product } \\
\text { growth and level }\end{array}$ & $\begin{array}{l}\text { Positive impact of national spillovers } \\
\text { for the USA }(0.56-0.59) \text { and of } \\
\text { international spillovers for Japan ( } 0.97 \\
-1.46)\end{array}$ \\
\hline $\begin{array}{l}\text { Geroski, Machin, Van } \\
\text { Reenan (1993) }\end{array}$ & UK & $\begin{array}{l}1972- \\
1983\end{array}$ & 721 & $\begin{array}{l}\text { No distance (intra } \\
\text { industry) }\end{array}$ & Profitability & $\begin{array}{l}\text { Producer and user-spillover non } \\
\text { significant in several models }\end{array}$ \\
\hline Harhoff (1998) & Germany & $1979-89$ & 443 & $\begin{array}{l}\text { Position in a R\&D- } \\
\text { type space }\end{array}$ & $\begin{array}{l}\text { Total product } \\
\text { growth }\end{array}$ & Positive impact (0.03) \\
\hline Jaffe (1986) & USA & $1972-77$ & 432 & $\begin{array}{l}\text { Position in a patent } \\
\text { space }\end{array}$ & $\begin{array}{l}\text { Gross operating } \\
\text { income; Tobin's } q\end{array}$ & Negative impact but slightly significant \\
\hline Jaffe (1988) & USA & $1972-77$ & 434 & $\begin{array}{l}\text { Position in a patent } \\
\text { space }\end{array}$ & $\begin{array}{l}\text { Total product } \\
\text { growth }\end{array}$ & $\begin{array}{l}\text { Positive impact ( } 0.01-1.35) \text { in several } \\
\text { specifications }\end{array}$ \\
\hline Jaffe (1989) & USA & $1972-77$ & 434 & $\begin{array}{l}\text { Position in a patent } \\
\text { space }\end{array}$ & $\begin{array}{l}\text { Growth of output, } \\
\text { profits, market } \\
\text { value }\end{array}$ & $\begin{array}{l}\text { Positive impact }(0.03-0.17) \text { in several } \\
\text { specifications }\end{array}$ \\
\hline Lindstrom (1999) & Sweden & $1979-94$ & 8441 & $\begin{array}{l}\text { No distance (intra } \\
\text { industry) }\end{array}$ & $\begin{array}{l}\text { Total product } \\
\text { growth }\end{array}$ & Positive impact $(0.27-0.97)$ \\
\hline Los (2000) & USA & 1974-91 & 680 & $\begin{array}{l}\text { No distance (intra } \\
\text { industry); patent } \\
\text { space }\end{array}$ & $\begin{array}{l}\text { Labor productivity } \\
\text { growth }\end{array}$ & $\begin{array}{l}\text { Positive impact: intra-industry }(0.35- \\
0.95) \text { and inter industry }(0.29-1.17)\end{array}$ \\
\hline Los, Verspagen (2000) & USA & $1974-93$ & 680 & $\begin{array}{l}\text { No distance (intra } \\
\text { industry); patent } \\
\text { space }\end{array}$ & $\begin{array}{l}\text { Labor productivity } \\
\text { growth }\end{array}$ & $\begin{array}{l}\text { Positive impact: intra industry }(0.39- \\
0.62) \text { and inter-industry }(0.42-0.68)\end{array}$ \\
\hline Macdissi, Negassi (2002) & France & $1990-96$ & 2763 & $\begin{array}{l}\text { Budget for } \\
\text { cooperations, capital } \\
\text { transactions }\end{array}$ & $\begin{array}{l}\text { Labor productivity } \\
\text { growth }\end{array}$ & $\begin{array}{l}\text { Positive impact: national spillovers } \\
(0.08-0.15) \text {; international }(0.11)\end{array}$ \\
\hline Orlando (2004) & USA & $1972-95$ & 515 & $\begin{array}{l}\text { Geographical and } \\
\text { industrial distance }\end{array}$ & Total product & $\begin{array}{l}\text { Positive impact from firms near } \\
\text { geographically and industrially close. }\end{array}$ \\
\hline Raut (1995) & India & $1975-86$ & 192 & $\begin{array}{l}\text { No distance (intra } \\
\text { industry) }\end{array}$ & Total product & Positive spillovers $(0.06-0.36)$ \\
\hline Van Reenen (1997) & UK & $1976-82$ & 598 & $\begin{array}{l}\text { No distance (intra } \\
\text { industry) }\end{array}$ & Employment & Non significant estimates \\
\hline Wakelin (2001) & UK & $1988-96$ & 98 & $\begin{array}{l}\text { No distance (intra } \\
\text { industry); distance in } \\
\text { a inventions space }\end{array}$ & $\begin{array}{l}\text { Labor productivity } \\
\text { growth }\end{array}$ & $\begin{array}{l}\text { Positive impact of intra industry } \\
\text { spillovers }(0.95) \text {; non significant inter } \\
\text { industry spillovers }\end{array}$ \\
\hline Wieser (2001) & $\begin{array}{l}\text { USA, } \\
\text { Europe }\end{array}$ & $1990-98$ & 2198 & $\begin{array}{l}\text { No distance (intra } \\
\text { industry) }\end{array}$ & $\begin{array}{l}\text { Labor productivity } \\
\text { growth }\end{array}$ & Non significant estimates \\
\hline
\end{tabular}


Table 3

SAMPLE DESCRIPTION

\begin{tabular}{|c|c|c|c|c|}
\hline $\begin{array}{c}\text { Manufacturing sector } \\
\text { Nace 2-digit }\end{array}$ & $\begin{array}{l}\text { Number of } \\
\text { firms } \\
(\%)\end{array}$ & $\begin{array}{l}\text { Number of } \\
\text { firms with } \\
\text { R\&D } \\
(\%)\end{array}$ & $\begin{array}{c}\text { Average R\&D } \\
\text { over sales } \\
\text { (s.d.) }\end{array}$ & $\begin{array}{l}\text { Average TFP } \\
\text { growth } \\
\text { (s.d.) }\end{array}$ \\
\hline 15, 16 - Food, tobacco & $\begin{array}{c}283 \\
(9.2 \%)\end{array}$ & $\begin{array}{c}62 \\
(21.9 \%) \\
\end{array}$ & $\begin{array}{c}0.004 \\
(0.012) \\
\end{array}$ & $\begin{array}{l}-0.025 \\
(0.084) \\
\end{array}$ \\
\hline 17- Textiles & $\begin{array}{c}298 \\
(9.7 \%)\end{array}$ & $\begin{array}{c}84 \\
(28.2 \%) \\
\end{array}$ & $\begin{array}{l}0.007 \\
(0.017)\end{array}$ & $\begin{array}{l}-0.027 \\
(0.095)\end{array}$ \\
\hline 18- Clothing & $\begin{array}{c}108 \\
(3.5 \%)\end{array}$ & $\begin{array}{c}27 \\
(25.0 \%)\end{array}$ & $\begin{array}{l}0.003 \\
(0.011)\end{array}$ & $\begin{array}{l}-0.026 \\
(0.083)\end{array}$ \\
\hline 19- Shoes, leather & $\begin{array}{c}163 \\
(5.3 \%)\end{array}$ & $\begin{array}{c}44 \\
(27.0 \%)\end{array}$ & $\begin{array}{c}0.006 \\
(0.015)\end{array}$ & $\begin{array}{l}-0.024 \\
(0.094)\end{array}$ \\
\hline $\begin{array}{l}\text { 20- Wood and wood products (no } \\
\text { furniture) }\end{array}$ & $\begin{array}{c}109 \\
(3.5 \%)\end{array}$ & $\begin{array}{c}18 \\
(16.5 \%)\end{array}$ & $\begin{array}{c}0.002 \\
(0.009)\end{array}$ & $\begin{array}{l}-0.006 \\
(0.074)\end{array}$ \\
\hline 21- Paper & $\begin{array}{c}98 \\
(3.2 \%)\end{array}$ & $\begin{array}{c}16 \\
(16.3 \%)\end{array}$ & $\begin{array}{l}0.003 \\
(0.010)\end{array}$ & $\begin{array}{l}-0.034 \\
(0.073)\end{array}$ \\
\hline 22- Printing and publishing & $\begin{array}{c}102 \\
(3.3 \%)\end{array}$ & $\begin{array}{c}13 \\
(12.7 \%) \\
\end{array}$ & $\begin{array}{c}0.002 \\
(0.007) \\
\end{array}$ & $\begin{array}{l}-0.032 \\
(0.079)\end{array}$ \\
\hline 23- Petroleum, coal & $\begin{array}{c}7 \\
(0.2 \%) \\
\end{array}$ & $\begin{array}{c}2 \\
(28.6 \%) \\
\end{array}$ & $\begin{array}{c}0.002 \\
(0.006) \\
\end{array}$ & $\begin{array}{l}-0.031 \\
(0.061) \\
\end{array}$ \\
\hline 24- Chemicals & $\begin{array}{c}121 \\
(3.9 \%)\end{array}$ & $\begin{array}{c}58 \\
(47.9 \%) \\
\end{array}$ & $\begin{array}{c}0.012 \\
(0.020)\end{array}$ & $\begin{array}{l}-0.013 \\
(0.077)\end{array}$ \\
\hline 25- Rubber, plastics & $\begin{array}{c}174 \\
(5.7 \%)\end{array}$ & $\begin{array}{c}56 \\
(32.2 \%)\end{array}$ & $\begin{array}{l}0.008 \\
(0.017)\end{array}$ & $\begin{array}{l}-0.018 \\
(0.086)\end{array}$ \\
\hline 26- Non metallic minerals & $\begin{array}{c}189 \\
(6.1 \%)\end{array}$ & $\begin{array}{c}32 \\
(16.9 \%)\end{array}$ & $\begin{array}{c}0.003 \\
(0.009)\end{array}$ & $\begin{array}{l}-0.025 \\
(0.098)\end{array}$ \\
\hline 27- Metals & $\begin{array}{c}102 \\
(3.3 \%)\end{array}$ & $\begin{array}{c}21 \\
(20.6 \%)\end{array}$ & $\begin{array}{c}0.004 \\
(0.012)\end{array}$ & $\begin{array}{l}-0.040 \\
(0.097)\end{array}$ \\
\hline 28- Metallic products & $\begin{array}{c}459 \\
(14.9 \%)\end{array}$ & $\begin{array}{c}88 \\
(19.2 \%)\end{array}$ & $\begin{array}{c}0.005 \\
(0.015)\end{array}$ & $\begin{array}{l}-0.030 \\
(0.090)\end{array}$ \\
\hline 29- Industrial machinery & $\begin{array}{c}317 \\
(10.3 \%) \\
\end{array}$ & $\begin{array}{c}153 \\
(48.3 \%) \\
\end{array}$ & $\begin{array}{c}0.012 \\
(0.020)\end{array}$ & $\begin{array}{c}0.012 \\
(0.072)\end{array}$ \\
\hline 30- Professional instruments & $\begin{array}{c}10 \\
(0.3 \%)\end{array}$ & $\begin{array}{c}6 \\
(60.0 \%)\end{array}$ & $\begin{array}{l}0.027 \\
(0.035)\end{array}$ & $\begin{array}{l}-0.023 \\
(0.035)\end{array}$ \\
\hline $\begin{array}{l}\text { 31- Electric and electronic } \\
\text { equipment }\end{array}$ & $\begin{array}{c}91 \\
(3.0 \%)\end{array}$ & $\begin{array}{c}36 \\
(39.6 \%)\end{array}$ & $\begin{array}{c}0.011 \\
(0.021)\end{array}$ & $\begin{array}{c}0.001 \\
(0.061)\end{array}$ \\
\hline $\begin{array}{l}\text { 32- Radio, TV and } \\
\text { telecommunications }\end{array}$ & $\begin{array}{c}71 \\
(2.3 \%)\end{array}$ & $\begin{array}{c}33 \\
(46.5 \%)\end{array}$ & $\begin{array}{l}0.015 \\
(0.023)\end{array}$ & $\begin{array}{l}-0.025 \\
(0.092)\end{array}$ \\
\hline $\begin{array}{l}\text { 33- Optical, jewelry, measurement } \\
\text { equipments }\end{array}$ & $\begin{array}{c}62 \\
(2.0 \%)\end{array}$ & $\begin{array}{c}33 \\
(53.2 \%)\end{array}$ & $\begin{array}{c}0.018 \\
(0.023)\end{array}$ & $\begin{array}{l}-0.018 \\
(0.094)\end{array}$ \\
\hline 34- Auto and moto vehicles & $\begin{array}{c}52 \\
(1.7 \%)\end{array}$ & $\begin{array}{c}14 \\
(26.9 \%)\end{array}$ & $\begin{array}{c}0.005 \\
(0.015)\end{array}$ & $\begin{array}{c}0.013 \\
(0.057)\end{array}$ \\
\hline 35- Other transportation equipment & $\begin{array}{c}24 \\
(0.8 \%)\end{array}$ & $\begin{array}{c}7 \\
(29.2 \%)\end{array}$ & $\begin{array}{l}0.008 \\
(0.016)\end{array}$ & $\begin{array}{c}0.022 \\
(0.075)\end{array}$ \\
\hline $\begin{array}{l}\text { 36- Misc.: furniture, musical } \\
\text { instruments, toys }\end{array}$ & $\begin{array}{c}237 \\
(7.7 \%)\end{array}$ & $\begin{array}{c}66 \\
(27.8 \%)\end{array}$ & $\begin{array}{c}0.005 \\
(0.014)\end{array}$ & $\begin{array}{l}-0.009 \\
(0.089)\end{array}$ \\
\hline Total & $\begin{array}{c}3077 \\
(100 \%)\end{array}$ & $\begin{array}{c}869 \\
(28.2 \%)\end{array}$ & $\begin{array}{c}0.007 \\
(0.016)\end{array}$ & $\begin{array}{l}-0.018 \\
(0.087)\end{array}$ \\
\hline
\end{tabular}


Table 4

R\&D ACTIVITY; DETERMINANTS OF CHOICE

\begin{tabular}{|c|c|c|c|c|}
\hline \multirow[t]{2}{*}{ Dependent variables: } & \multicolumn{2}{|c|}{$\begin{array}{c}\text { PROBIT } \\
D\left(D_{i}=1 \text { if } R \& D\right. \\
\left.\text { spending }{ }_{i}>0\right)\end{array}$} & \multicolumn{2}{|c|}{$\begin{array}{c}\text { TOBIT } \\
R \& D \text { spending over } \\
\text { sales }\end{array}$} \\
\hline & Coeff. & t-ratio & Coeff. & t-ratio \\
\hline constant & -2.465 & $-13.450^{* \star \star}$ & -0.080 & $-12.293^{\star * \star}$ \\
\hline Regional dummy for Northwest & 0.194 & 2.098 ** & 0.007 & $2.084^{\star \star}$ \\
\hline Regional dummy for Northeast & 0.204 & $2.178 * *$ & 0.008 & $2.400 * *$ \\
\hline Regional dummy for Center & 0.283 & $2.957 * * \star$ & 0.011 & $3.195 * * *$ \\
\hline Share of intangible assets & 0.208 & 0.396 & 0.004 & 0.202 \\
\hline Long term debts over total assets & 0.553 & $3.150 * * *$ & 0.012 & $1.990 * *$ \\
\hline Short term debts over total assets & 0.347 & 0.918 & 0.022 & $1.734 *$ \\
\hline Holding/control of other firms within a group (dummy) & 0.080 & 0.808 & 0.002 & 0.580 \\
\hline Log of number of employees & 0.254 & 8.157 *** & 0.005 & $4.920 * \star \star$ \\
\hline Dummy $=1$ if the firms exports & 0.425 & $6.751 * \star \star$ & 0.015 & $6.771^{\star * \star}$ \\
\hline Age of firms at the year 2000 & -0.002 & -0.046 & 0.001 & 0.566 \\
\hline Human capital index & 0.173 & $6.208 * \star *$ & 0.006 & $6.815^{\star \star \star}$ \\
\hline SIGMA & & & 0.037 & $36.660 * * *$ \\
\hline $\mathrm{N}$ & 3077 & & 3077 & \\
\hline $\begin{array}{l}\text { Pseudo } \mathrm{R}^{2} \\
\text { ANOVA based fit measure }\end{array}$ & 0.448 & & 0.513 & \\
\hline Log likelihood function & -1590.5 & & 753.1 & \\
\hline
\end{tabular}

Includes 21 sectorial dummies. ${ }^{\star \star \star},{ }^{\star \star},{ }^{*}:$ 1\%, 5\%, 10\% significance level. 
Table 5

R\&D AND PRODUCTIVITY: PRIVATE RETURNS AND INTRA INDUSTRY SPILLOVERS

\begin{tabular}{|c|c|c|c|c|c|c|}
\hline \multicolumn{3}{|c|}{ Dependent variable: TFP growth 1998 - 2000} & \multirow{2}{*}{\multicolumn{2}{|c|}{ Wooldridge 2SLS, probit selection }} & \multirow{2}{*}{\multicolumn{2}{|c|}{ Wooldridge 2SLS; tobit selection }} \\
\hline & \multicolumn{2}{|c|}{ Heckman 2-step procedure } & & & & \\
\hline & Coeff. t-ratio & Coeff. t-ratio & Coeff. t-ratio & Coeff. t-ratio & Coeff. t-ratio & Coeff. t-ratio \\
\hline Constant & $-0.008-1.111$ & $-0.024-5.426^{* \star *}$ & $-0.008-1.074$ & $-0.025-5.305^{\star \star *}$ & $-0.005-0.738$ & $-0.021-4.625^{\star \star \star}$ \\
\hline $\begin{array}{l}\text { Regional dummy for } \\
\text { Northwest }\end{array}$ & $-0.015-2.795 * \star \star$ & $-0.014-2.691^{* \star *}$ & $-0.015-2.633^{* * *}$ & $-0.014-2.629 * * *$ & $-0.014-2.547^{\star *}$ & $-0.014-2.580 * \star \star$ \\
\hline $\begin{array}{l}\text { Regional dummy for } \\
\text { Northeast }\end{array}$ & $-0.010-1.865^{*}$ & $-0.009-1.682^{*}$ & $-0.010-1.749 *$ & $-0.009-1.648 *$ & $-0.010-1.790 *$ & $-0.009-1.707 *$ \\
\hline $\begin{array}{l}\text { Regional dummy for } \\
\text { Center }\end{array}$ & $-0.007-1.343$ & $-0.009-1.628$ & $-0.008-1.262$ & $-0.009-1.593$ & $-0.008-1.301$ & $-0.009-1.625$ \\
\hline$D_{i}=1$ if $\left.R \& D>0\right)$ & $0.0322 .887^{\star \star \star}$ & $0.0515 .609 * \star *$ & $0.0333 .138^{* \star *}$ & 0.0515 .518 *** & & \\
\hline $\begin{array}{l}\text { R\&D spending over } \\
\text { sales }\end{array}$ & & & & & $1.1972 .633^{\star \star \star *}$ & $1.6504 .771^{\star \star \star}$ \\
\hline $\begin{array}{l}\text { Intra-industry } \\
\text { spillovers }\end{array}$ & & $0.0552 .129 * *$ & & $0.0552 .037^{* *}$ & & $0.044 \quad 1.578$ \\
\hline Inverse Mill's ratio & $-0.020-2.943^{* * *}$ & $-0.031-5.446^{* * *}$ & & & & \\
\hline $\begin{array}{l}\text { Includes } 21 \text { sectorial } \\
\text { dummies? }\end{array}$ & YES & NO & YES & NO & YES & NO \\
\hline $\mathrm{N}$ & 3077 & 3077 & 3077 & 3077 & 3077 & 3077 \\
\hline RSS & 22.05 & 22.62 & 22.67 & 24.13 & 22.87 & 24.34 \\
\hline $\mathrm{F}$ & 4.260 *** & $7.650 * * *$ & 4.080 *** & 7.210 *** & 4.540 *** & 7.880 *** \\
\hline LOG-LIK & 3231 & 3192 & 3187 & 3093 & 3175 & 3080 \\
\hline $\mathrm{RHO}$ & -0.233 & -0.349 & & & & \\
\hline
\end{tabular}


TABLE 6

DEMAND-DRIVEN SPILLOVER

\begin{tabular}{|c|c|c|c|c|c|c|c|c|c|c|c|c|}
\hline \multicolumn{13}{|c|}{ Dependent variable: TFP growth 1998 - 2000} \\
\hline & \multicolumn{6}{|c|}{ 2SLS, probit selection } & \multicolumn{6}{|c|}{ 2SLS, tobit selection } \\
\hline & Coeff. & t-ratio & & Coeff. & t-ratio & & Coeff. & t-ratio & & Coeff. & t-ratio & \\
\hline Constant & -0.022 & -4.668 & *** & -0.022 & -4.564 & *** & -0.018 & -3.807 & *** & -0.017 & -3.716 & *** \\
\hline Regional dummy for Northwest & -0.012 & -2.375 & ** & -0.012 & -2.323 & $\star \star *$ & -0.012 & -2.263 & ** & -0.012 & -2.229 & ** \\
\hline Regional dummy for Northeast & -0.008 & -1.496 & & -0.008 & -1.493 & & -0.008 & -1.533 & & -0.009 & -1.552 & \\
\hline Regional dummy for Center & -0.009 & -1.626 & & -0.009 & -1.663 & * & -0.010 & -1.709 & * & -0.010 & -1.759 & * \\
\hline$D_{i}=1$ if $R \& D>0$ ) & 0.052 & 5.574 & *** & 0.054 & 5.754 & *** & & & & & & \\
\hline R\&D spending over sales & & & & & & & 1.747 & 4.944 & *** & 1.845 & 5.166 & *** \\
\hline Intra-industry spillovers & 0.058 & 2.141 & ** & & & & 0.047 & 1.659 & * & & & \\
\hline $\begin{array}{l}\text { Demand Spillovers } \\
\text { from other industries }\end{array}$ & -0.208 & -1.595 & & -0.230 & -1.703 & * & -0.313 & -2.337 & ** & -0.329 & -2.387 & ** \\
\hline $\begin{array}{l}\text { Demand Spillovers* } \\
\text { intra-industry spillovers }\end{array}$ & & & & 1.671 & 1.130 & & & & & 0.972 & 0.630 & \\
\hline N & 3077 & & & 3077 & & & 3077 & & & 3077 & & \\
\hline RSS & 24.13 & & & 24.28 & & & 24.50 & & & 24.75 & & \\
\hline LOG-LIK & 3165 & & & 3165 & & & 3165 & & & 3165 & & \\
\hline
\end{tabular}

***, **, *: 1\%, 5\%, 10\% significance level.

TABLE 7

SUPPLY-DRIVEN SPILLOVER

\begin{tabular}{|c|c|c|c|c|c|c|c|c|c|c|c|c|}
\hline \multicolumn{13}{|c|}{ Dependent variable: TFP growth $1998-2000$} \\
\hline & \multicolumn{6}{|c|}{ Wooldridge 2SLS, probit selection } & \multicolumn{6}{|c|}{ Wooldridge 2SLS, tobit selection } \\
\hline & Coeff. & t-ratio & & Coeff. & t-ratio & & Coeff. & t-ratio & & Coeff. & t-ratio & \\
\hline Constant & -0.026 & -5.718 & *** & -0.026 & -5.681 & *** & -0.023 & -5.341 & *** & -0.023 & -5.300 & $\star \star *$ \\
\hline Regional dummy for Northwest & -0.015 & -3.001 & *** & -0.015 & -2.999 & *** & -0.015 & -2.909 & 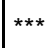 & -0.015 & -2.910 & $\star \star \star *$ \\
\hline Regional dummy for Northeast & -0.010 & -1.836 & * & -0.010 & -1.833 & * & -0.010 & -1.790 & * & -0.010 & -1.790 & * \\
\hline Regional dummy for Center & -0.007 & -1.322 & & -0.007 & -1.329 & & -0.007 & -1.253 & & -0.007 & -1.262 & \\
\hline$D_{i}=1$ if $\left.R \& D>0\right)$ & 0.031 & 3.156 & *** & 0.031 & 3.233 & $\star \star \star *$ & & & & & & \\
\hline R\&D spending over sales & & & & & & & 0.832 & 2.280 & ** & 0.849 & 2.370 & ** \\
\hline Intra-industry spillovers & 0.035 & 1.329 & & & & & 0.032 & 1.166 & & & & \\
\hline $\begin{array}{l}\text { Supply Spillovers } \\
\text { from other industries }\end{array}$ & 0.481 & 5.582 & *** & 0.451 & 4.997 & $\star \star \star \star$ & 0.502 & 5.769 & $* \star \star$ & 0.474 & 5.246 & $* * *$ \\
\hline $\begin{array}{l}\text { Supply Spillovers * } \\
\text { intra-industry spillovers }\end{array}$ & & & & 1.527 & 1.578 & & & & & 1.389 & 1.420 & \\
\hline $\mathrm{N}$ & 3077 & & & 3077 & & & 3077 & & & 3077 & & \\
\hline RSS & 22.96 & & & 22.98 & & & 22.78 & & & 22.80 & & \\
\hline LOG-LIK & 3165 & & & 3165 & & & 3165 & & & 3165 & & \\
\hline
\end{tabular}

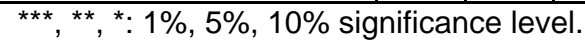




\section{APPENDIX}

Table A.1

Input - output matrix - demand side

\begin{tabular}{|c|c|c|c|c|c|c|c|c|c|c|c|c|c|c|c|c|c|c|c|c|c|}
\hline \multirow{2}{*}{\multicolumn{2}{|c|}{ sectors }} & \multicolumn{19}{|c|}{ supplier } & \multirow[b]{2}{*}{ Sum* } \\
\hline & & $\begin{array}{l}15, \\
16\end{array}$ & $\begin{array}{l}17 \\
18\end{array}$ & 19 & 20 & 21 & 22 & 23 & 24 & 25 & 26 & 27 & 28 & 29 & $\begin{array}{l}30, \\
31\end{array}$ & 32 & 33 & 34 & 35 & 36 & \\
\hline \multirow{19}{*}{ 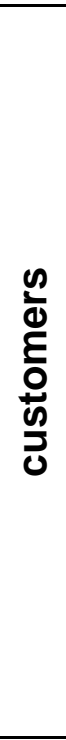 } & 15,16 & 0,1 & 29,2 & 0,3 & 0,1 & 0,4 & 2,2 & 0,4 & 0,4 & 0,7 & 2,2 & 2,3 & 0,3 & 1,3 & 0,7 & 0,1 & 0,1 & 0,1 & 0,1 & 0,1 & 40,9 \\
\hline & 17,18 & 0,0 & 0,1 & 58,0 & 1,5 & 0,3 & 0,5 & 0,3 & 0,7 & 8,7 & 1,3 & 0,0 & 0,4 & 0,4 & 0,6 & 0,2 & 0,1 & 0,1 & 0,0 & 0,0 & 73,3 \\
\hline & 19 & 0,1 & 15,8 & 2,8 & 33,9 & 0,4 & 1,5 & 0,6 & 0,5 & 4,4 & 10,4 & 0,1 & 0,4 & 5,5 & 0,8 & 0,1 & 0,1 & 0,1 & 0,0 & 0,0 & 77,5 \\
\hline & 20 & 0,0 & 0,0 & 0,1 & 0,0 & 57,6 & 1,0 & 0,2 & 1,0 & 3,9 & 1,7 & 1,5 & 1,3 & 4,1 & 0,9 & 0,2 & 0,1 & 0,1 & 0,1 & 0,0 & 73,9 \\
\hline & 21 & 1,5 & 0,3 & 1,7 & 0,2 & 0,4 & 45,5 & 3,6 & 0,6 & 12,8 & 2,3 & 0,1 & 0,8 & 0,2 & 1,1 & 0,3 & 0,1 & 0,1 & 0,0 & 0,0 & 71,5 \\
\hline & 22 & 0,0 & 0,0 & 0,4 & 0,0 & 0,2 & 31,7 & 22,8 & 0,3 & 5,1 & 0,9 & 0,3 & 1,4 & 0,6 & 1,2 & 0,4 & 0,1 & 0,1 & 0,1 & 0,1 & 65,7 \\
\hline & 23 & 0,3 & 33,5 & 0,0 & 0,0 & 0,0 & 0,0 & 0,0 & 17,0 & 1,6 & 0,0 & 0,2 & 0,1 & 0,6 & 0,5 & 0,2 & 0,0 & 0,1 & 0,0 & 0,0 & 54,2 \\
\hline & 24 & 1,7 & 3,7 & 0,2 & 0,1 & 0,3 & 2,3 & 1,9 & 5,2 & 45,3 & 3,3 & 3,6 & 1,0 & 0,9 & 0,9 & 0,6 & 0,1 & 0,1 & 0,0 & 0,0 & 71,2 \\
\hline & 25 & 0,0 & 0,0 & 2,7 & 0,3 & 0,6 & 2,7 & 0,5 & 0,8 & 43,4 & 15,7 & 0,8 & 2,3 & 3,6 & 1,0 & 1,0 & 0,1 & 0,1 & 0,2 & 0,0 & 75,9 \\
\hline & 26 & 14,2 & 0,0 & 0,2 & 0,0 & 1,4 & 2,6 & 1,0 & 3,1 & 5,8 & 1,9 & 25,0 & 3,3 & 2,3 & 1,7 & 0,6 & 0,2 & 0,2 & 0,2 & 0,0 & 63,8 \\
\hline & 27 & 0,4 & 0,0 & 0,2 & 0,0 & 0,2 & 0,3 & 0,9 & 6,0 & 4,9 & 0,6 & 3,9 & 32,8 & 3,2 & 1,5 & 1,0 & 0,1 & 0,1 & 0,0 & 0,1 & 56,1 \\
\hline & 28 & 0,4 & 0,0 & 0,2 & 0,0 & 1,1 & 0,7 & 0,8 & 1,0 & 2,6 & 1,9 & 1,5 & 39,8 & 18,6 & 1,8 & 1,2 & 0,1 & 0,2 & 0,2 & 0,1 & 72,2 \\
\hline & 29 & 0,0 & 0,0 & 0,1 & 0,0 & 0,3 & 0,6 & 0,8 & 0,4 & 1,5 & 4,8 & 0,5 & 14,5 & 25,6 & 19,3 & 5,2 & 3,0 & 0,4 & 0,5 & 0,0 & 77,4 \\
\hline & 30,31 & 0,3 & 0,0 & 0,2 & 0,0 & 0,3 & 0,9 & 0,4 & 0,4 & 3,6 & 5,7 & 1,4 & 18,5 & 7,4 & 1,9 & 31,7 & 7,9 & 0,5 & 0,1 & 0,0 & 81,4 \\
\hline & 32 & 0,0 & 0,0 & 0,2 & 0,0 & 0,3 & 0,9 & 1,2 & 0,2 & 2,6 & 6,1 & 3,0 & 4,6 & 4,8 & 2,1 & 9,9 & 29,3 & 1,3 & 0,0 & 0,0 & 66,6 \\
\hline & 33 & 0,1 & 0,0 & 0,2 & 0,6 & 0,5 & 1,0 & 0,9 & 0,4 & 2,1 & 4,3 & 1,5 & 10,1 & 17,5 & 1,9 & 1,0 & 4,9 & 21,3 & 0,1 & 0,0 & 68,5 \\
\hline & 34 & 0,0 & 0,0 & 1,2 & 0,2 & 0,1 & 0,2 & 0,6 & 0,5 & 2,2 & 8,3 & 1,4 & 10,0 & 20,0 & 4,5 & 6,2 & 0,7 & 0,9 & 26,0 & 0,0 & 83,1 \\
\hline & 35 & 0,0 & 0,0 & 0,4 & 0,0 & 2,5 & 0,4 & 0,6 & 0,4 & 2,1 & 4,9 & 0,9 & 12,8 & 10,9 & 8,6 & 3,9 & 4,6 & 1,6 & 0,1 & 25,4 & 80,1 \\
\hline & 36 & 1,2 & 0,0 & 2,4 & 1,8 & 29,3 & 1,3 & 0,5 & 0,5 & 4,4 & 3,2 & 1,7 & 18,5 & 5,6 & 1,0 & 0,7 & 0,3 & 0,1 & 0,0 & 0,0 & 72,3 \\
\hline & $\begin{array}{c}\text { sample } \\
\text { mean }\end{array}$ & 1,1 & 4,3 & 3,8 & 2,0 & 5,1 & 5,1 & 2,0 & 2,1 & 8,3 & 4,2 & 2,6 & 9,1 & 7,0 & 2,7 & 3,4 & 2,7 & 1,4 & 1,5 & 1,4 & 69,8 \\
\hline
\end{tabular}

Each cell reports the share of purchases of industries in rows from industries in columns, over total purchases

See Table 3 for the description of the manufacturing sectors

*it represents overall share of purchases of manufacturing sectors in rows from manufacturing sectors 
Table A.2

Input - output matrix - supply side

\begin{tabular}{|c|c|c|c|c|c|c|c|c|c|c|c|c|c|c|c|c|c|c|c|c|c|}
\hline \multirow{2}{*}{\multicolumn{2}{|c|}{ sectors }} & \multicolumn{19}{|c|}{ customers } & \multirow[b]{2}{*}{ Sum* } \\
\hline & & $\begin{array}{l}15, \\
16\end{array}$ & $\begin{array}{l}17 \\
18\end{array}$ & 19 & 20 & 21 & 22 & 23 & 24 & 25 & 26 & 27 & 28 & 29 & $\begin{array}{l}30, \\
31\end{array}$ & 32 & 33 & 34 & 35 & 36 & \\
\hline \multirow{19}{*}{$\frac{\text { の }}{\frac{0}{\frac{0}{2}}}$} & 15,16 & 40,8 & 0,1 & 5,4 & 0,0 & 0,1 & 0,0 & 2,0 & 3,0 & 0,0 & 0,0 & 0,0 & 0,0 & 0,0 & 0,0 & 0,0 & 0,0 & 0,0 & 0,0 & 0,0 & 51,4 \\
\hline & 17,18 & 0,5 & 83,9 & 1,1 & 0,0 & 0,5 & 0,1 & 0,0 & 0,3 & 1,2 & 0,2 & 0,3 & 0,3 & 0,3 & 0,2 & 0,2 & 0,1 & 0,9 & 0,1 & 1,1 & 91,4 \\
\hline & 19 & 0,6 & 10,0 & 76,9 & 0,0 & 0,4 & 0,1 & 0,0 & 0,4 & 0,9 & 0,0 & 0,1 & 0,2 & 0,3 & 0,0 & 0,1 & 0,5 & 0,8 & 0,0 & 5,0 & 96,2 \\
\hline & 20 & 1,4 & 0,9 & 0,4 & 34,7 & 0,3 & 0,2 & 0,0 & 0,6 & 0,8 & 1,7 & 0,3 & 2,4 & 0,9 & 0,4 & 0,3 & 0,2 & 0,2 & 1,4 & 35,9 & 82,8 \\
\hline & 21 & 7,4 & 1,2 & 1,2 & 0,5 & 29,4 & 20,4 & 0,0 & 4,7 & 2,7 & 2,7 & 0,4 & 1,3 & 1,7 & 0,9 & 0,6 & 0,3 & 0,3 & 0,2 & 1,3 & 77,2 \\
\hline & 22 & 1,6 & 1,0 & 0,6 & 0,1 & 2,8 & 18,0 & 0,0 & 4,7 & 0,7 & 1,3 & 1,6 & 1,8 & 2,6 & 0,5 & 1,1 & 0,3 & 1,0 & 0,3 & 0,6 & 40,8 \\
\hline & 23 & 0,7 & 1,0 & 0,3 & 0,3 & 0,2 & 0,1 & 6,4 & 5,9 & 0,5 & 1,8 & 5,1 & 1,1 & 0,6 & 0,2 & 0,1 & 0,1 & 0,4 & 0,1 & 0,3 & 25,2 \\
\hline & 24 & 0,7 & 6,8 & 1,2 & 0,6 & 2,7 & 1,1 & 0,4 & 28,9 & 13,9 & 1,9 & 2,4 & 1,5 & 1,4 & 1,1 & 0,6 & 0,2 & 1,0 & 0,3 & 1,4 & 68,1 \\
\hline & 25 & 5,6 & 2,5 & 6,6 & 0,7 & 1,2 & 0,4 & 0,0 & 5,0 & 12,1 & 1,5 & 0,7 & 2,7 & 10,2 & 4,3 & 3,4 & 1,0 & 8,9 & 1,7 & 2,5 & 70,9 \\
\hline & 26 & 5,3 & 0,0 & 0,0 & 0,5 & 0,0 & 0,1 & 0,1 & 5,1 & 0,6 & 18,1 & 4,2 & 2,0 & 1,0 & 1,0 & 1,5 & 0,3 & 1,4 & 0,3 & 1,2 & 42,8 \\
\hline & 27 & 0,4 & 0,4 & 0,1 & 0,2 & 0,2 & 0,4 & 0,0 & 0,8 & 0,9 & 1,3 & 19,0 & 27,9 & 15,1 & 6,8 & 1,3 & 1,1 & 5,3 & 2,2 & 7,2 & 90,7 \\
\hline & 28 & 1,7 & 0,4 & 1,9 & 0,9 & 0,0 & 0,2 & 0,2 & 0,7 & 1,5 & 1,0 & 2,0 & 14,3 & 29,1 & 3,0 & 1,4 & 2,1 & 11,5 & 2,1 & 2,4 & 76,3 \\
\hline & 29 & 2,1 & 1,4 & 0,6 & 0,4 & 0,6 & 0,7 & 0,3 & 1,5 & 0,9 & 1,6 & 2,0 & 3,0 & 47,5 & 1,7 & 1,3 & 0,5 & 5,6 & 3,5 & 0,9 & 76,2 \\
\hline & 30,31 & 0,4 & 0,4 & 0,1 & 0,1 & 0,2 & 0,2 & 0,1 & 1,0 & 0,9 & 0,5 & 1,4 & 1,9 & 12,4 & 30,4 & 6,3 & 0,3 & 7,6 & 1,6 & 0,6 & 66,4 \\
\hline & 32 & 0,3 & 0,3 & 0,1 & 0,1 & 0,1 & 0,1 & 0,0 & 0,3 & 0,1 & 0,3 & 0,1 & 0,3 & 13,2 & 12,5 & 34,6 & 2,4 & 1,6 & 3,4 & 0,6 & 70,6 \\
\hline & 33 & 1,0 & 0,8 & 0,2 & 0,2 & 0,3 & 0,3 & 0,4 & 0,7 & 0,5 & 1,1 & 0,7 & 1,5 & 4,5 & 2,3 & 4,2 & 27,5 & 5,6 & 3,3 & 0,3 & 55,4 \\
\hline & 34 & 0,3 & 0,1 & 0,0 & 0,0 & 0,0 & 0,1 & 0,0 & 0,1 & 0,3 & 0,3 & 0,0 & 0,4 & 2,1 & 0,1 & 0,0 & 0,0 & 53,0 & 0,1 & 0,0 & 57,1 \\
\hline & 35 & 0,9 & 0,0 & 0,0 & 0,0 & 0,0 & 0,1 & 0,0 & 0,0 & 0,0 & 0,0 & 0,2 & 0,5 & 0,2 & 0,1 & 0,0 & 0,0 & 0,1 & 30,6 & 0,0 & 32,8 \\
\hline & 36 & 1,0 & 6,6 & 1,4 & 0,6 & 0,2 & 0,7 & 0,0 & 1,2 & 0,8 & 1,5 & 1,2 & 1,6 & 3,2 & 0,6 & 1,7 & 2,0 & 2,9 & 0,2 & 34,9 & 62,5 \\
\hline & $\begin{array}{c}\text { sample } \\
\text { mean }\end{array}$ & 3,8 & 6,2 & 5,2 & 2,1 & 2,1 & 2,3 & 0,5 & 3,4 & 2,1 & 1,9 & 2,2 & 3,4 & 7,7 & 3,5 & 3,1 & 2,0 & 5,7 & 2,7 & 5,1 & 65,0 \\
\hline
\end{tabular}

Each cell reports the share of sales of industries in rows to industries in columns, over total sales

See Table 3 for the description of the manufacturing sectors

*it represents overall share of sales of manufacturing sectors in rows to manufacturing sectors 